University of Nebraska - Lincoln

DigitalCommons@University of Nebraska - Lincoln

\title{
Fat Dynamics of Arctic-Nesting Sandpipers During Spring in Mid- Continental North America
}

\author{
Gary Krapu \\ USGS Northern Prairie Wildlife Research Center, gkrapu@usgs.gov \\ Jan Eldridge \\ USGS Northern Prairie Wildlife Research Center \\ Cherri Grato-Trevor \\ Canadian Wildlife Service, Environment Canada, Prairie and Northern Wildlife Research Centre \\ Deborah Buhl \\ USGS Northern Prairie Wildlife Research Center, dbuhl@usgs.gov
}

Follow this and additional works at: https://digitalcommons.unl.edu/usgsnpwrc

Part of the Other International and Area Studies Commons

Krapu, Gary; Eldridge, Jan; Grato-Trevor, Cherri; and Buhl, Deborah, "Fat Dynamics of Arctic-Nesting Sandpipers During Spring in Mid-Continental North America" (2006). USGS Northern Prairie Wildlife Research Center. 41.

https://digitalcommons.unl.edu/usgsnpwrc/41

This Article is brought to you for free and open access by the US Geological Survey at DigitalCommons@University of Nebraska - Lincoln. It has been accepted for inclusion in USGS Northern Prairie Wildlife Research Center by an authorized administrator of DigitalCommons@University of Nebraska - Lincoln. 


\title{
FAT DYNAMICS OF ARCTIC-NESTING SANDPIPERS DURING SPRING IN MID-CONTINENTAL NORTH AMERICA
}

\author{
Gary L. Krapu, ${ }^{1,3}$ Jan L. Eldridge, ${ }^{1,4}$ Cheri L. Gratto-Trevor ${ }^{2}$ \\ and Deborah A. Buhl ${ }^{1}$ \\ ${ }^{1}$ U.S. Geological Survey, Northern Prairie Wildlife Research Center, Jamestown, North Dakota 58401, USA; and \\ ${ }^{2}$ Canadian Wildlife Service, Environment Canada, Prairie and Northern Wildlife Research Centre, Saskatoon, \\ Saskatchewan S7N OX4, Canada
}

\begin{abstract}
Авstract. - We measured fresh body mass, total body fat, and fat-free dry mass (FFDM) of three species of Arctic-nesting calidrid sandpipers (Baird's Sandpiper [Calidris bairdii], hereafter "BASA"; Semipalmated Sandpiper [C. pusilla], hereafter "SESA"; and White-rumped Sandpiper [C. fuscicollis], hereafter "WRSA") during spring stopovers in the Prairie Pothole Region (PPR) of North Dakota, and evaluated the contribution of stored fat to (1) energy requirements for migration to their Arcticbreeding grounds and (2) nutrient needs for reproduction. All spring migrant WRSA $(n=124)$ and BASA $(n=111)$, and all but 2 of 99 SESA we collected were $\geq 2$ years old. Male and female BASA migrated through North Dakota concurrently, male SESA averaged earlier than females, and WRSA males preceded females. Fat indices (ratio of fat to FFDM) of male and female SESA and WRSA averaged approximately twice those of male and female BASA. Total body fat of male and female BASA increased with date in spring 1980, but not in 1981; slopes were similar for both sexes each year. Male and female SESA arrived lean in 1980 and 1981, and total body fat increased with date in both years, with similar slopes for all combinations of sex and year. Male and female WRSA arrived lean in 1980-1981 and 1981, respectively, and total body fat increased with date, whereas females arrived with fat reserves already acquired in 1980. Interspecific and sex differences in migration schedules probably contributed to variation in fat storage patterns by affecting maintenance energy costs and food availability. Estimated flight ranges of BASA suggest that few could have met their energy needs for migration to the breeding grounds exclusively from fat stored by the time of departure from North Dakota. Estimated flight ranges of SESA and WRSA, along with fresh body masses of both species when live-trapped on or near their breeding grounds in northern Canada, suggest that major parts of both populations stored adequate fat by departure from temperate mid-continental North America to meet their energy requirements for migration and part of their nutrient needs for reproduction. Received 29 November 2004, accepted 20 August 2005.
\end{abstract}

Key words: Arctic breeding grounds, Baird's Sandpiper, Calidris bairdii, C. fuscicollis, C. pusilla, Canada, fat storage, flight ranges, North Dakota, Prairie Pothole Region, Semipalmated Sandpiper, White-rumped Sandpiper.

\section{Dinámica de la Grasa en Chorlos que Nidifican en el Ártico durante la Primavera} en el Área Continental Central de América del Norte

Resumen.-Medimos la masa corporal fresca, la grasa corporal total y la masa seca sin grasa (MSSG) de tres especies de chorlos del género Calidris (Calidris bairdii, C. pusilla y C. fuscicollis) que nidifican en el Ártico durante escalas migratorias en la

\footnotetext{
${ }^{3}$ E-mail: gary_krapu@usgs.gov

${ }^{4}$ Present address: 246 Cove Lane, Hudson, Wisconsin 54016, USA.
} 
región de la Pradera Pothole de Dakota del Norte. Además, evaluamos la contribución de la grasa almacenada a los requerimientos energéticos para la migración a los sitios reproductivos en el ártico, y a las necesidades de nutrientes para la reproducción. Todas las aves migratorias de primavera de C. fuscicollis $(n=124)$ y C. bairdii $(n=111)$, y todas excepto 2 de las 99 aves de C. pusilla que colectamos fueron de dos años de edad. Los machos y las hembras de C. bairdii migraron conjuntamente a través de Dakota del Norte, los machos de C. pusilla migraron en promedio más temprano que las hembras y los machos de C. fuscicollis precedieron a las hembras. Los índices de la grasa (cociente entre grasa y MSSG) promedio de los machos y hembras de C. pusilla y C. fuscicollis fueron aproximadamente el doble que los de los machos y hembras de $C$. bairdii. La grasa corporal total de los machos y las hembras de C. bairdii incrementaron con la fecha en la primavera de 1980, pero no en 1981; las pendientes fueron similares para ambos sexos en cada año. Los machos y las hembras de C. pusilla llegaron magros en 1980 y 1981, y la grasa corporal total incrementó con la fecha en ambos años, con pendientes similares para todas las combinaciones de sexo y año. Los machos y las hembras de C. fuscicollis llegaron magros en 1980-1981 y 1981, respectivamente, y la grasa corporal total incrementó con la fecha, mientras que las hembras llegaron con reservas de grasa que ya habían adquirido en 1980. Diferencias intra-específicas y entre los sexos en los esquemas de migración probablemente contribuyeron a la variación en los patrones de almacenamiento de grasa mediante la afectación de los costos energéticos de mantenimiento y la disponibilidad de alimentos. Los rangos de vuelo estimados de C. bairdii sugieren que pocos individuos podrían haber satisfecho sus requerimientos energéticos para la migración a sus sitios reproductivos exclusivamente a partir de la grasa almacenada hasta el momento de partida desde Dakota del Norte. Los rangos estimados de vuelo de C. pusilla y C. fuscicollis, junto con las masas corporales frescas de ambas especies cuando fueron atrapadas en o cerca de los sitios reproductivos en el norte de Canadá, sugieren que la mayor parte de ambas poblaciones almacenaron una cantidad adecuada de grasa hacia el tiempo de partida de las áreas templadas del área continental central de América del Norte, como para satisfacer sus requerimientos energéticos para la migración y para parte de sus necesidades de nutrientes para la reproducción.

TEN SPECIES OF sandpipers of the genus Calidris migrate through mid-continental North America during spring while en route to their Arctic breeding grounds (Skagen et al. 1999). Fat is stored by at least some of these species during spring stopovers in the Central Plains (Harrington et al. 1991, Skagen and Knopf 1994), but the magnitude of fat storage before departure from temperate North America is poorly known. The last major opportunity for sandpipers to store large amounts of fat occurs when the birds are in the Prairie Pothole Region (PPR) of the north-central United States and adjacent parts of south-central Canada (Krapu and Duebbert 1989). To gain insight into fat storage by Arctic-nesting sandpipers before their departure from the PPR, we selected adult ( $\geq 2$ years old) male and female Baird's Sandpipers (Calidris bairdii; hereafter "BASA"), Semipalmated Sandpipers (C. pusilla; hereafter
"SESA"), and White-rumped Sandpipers (C. fuscicollis; hereafter "WRSA") for study. Specifically, we measured total body fat of BASA, SESA, and WRSA throughout their spring stopovers in eastern North Dakota and modeled body fat as a function of sex, year, date, and body size.

The amount of fat that Arctic-nesting sandpipers store before departing from North Dakota in spring may be influenced by timing of migration. Migration schedules differ among species of sandpipers (Skagen et al. 1999), exposing species to varying ambient temperatures (and energy costs) and potential differences in foraging conditions (and nutrient intake). Spring migration schedules also may differ between sexes, potentially affecting magnitude and patterns of fat storage. To gain insight into the potential influence of migration schedules of adult male and female BASA, SESA, and WRSA on fat storage during spring 
migration, we evaluated relationships between chronology of migration and magnitude and patterns of fat storage.

The significance of fat reserves acquired by Arctic-nesting sandpipers in temperate North America for meeting sandpiper nutrient requirements for migration to the breeding grounds and for reproduction remains poorly understood. The need for greater insight is heightened by evidence that populations of some species, including SESA and BASA, may be declining for unknown reasons (Morrison et al. 1994, 2001). To evaluate use of stored fat by adult male and female BASA, SESA, and WRSA, we calculated their flight ranges from North Dakota and estimated the amounts of fat remaining for reproduction after energy needs for migration had been met. For SESA and WRSA, we obtained independent estimates of the amounts of fat retained upon arrival at or near breeding sites by measuring body masses of live-trapped unsexed individuals shortly after their arrival near Churchill, Manitoba, on the west side of Hudson Bay. Semipalmated Sandpipers and WRSA that stop in the Churchill area in spring are part of the same populations that migrate through North Dakota (Morrison 1984).

\section{Methods}

We conducted the study within a $100 \times 30$ $\mathrm{km}$ area in Stutsman and Kidder counties of south-central North Dakota. The western four-fifths of the study area was located within the Missouri Coteau, and the remainder was on the glaciated Drift Plain; both glacial land forms are part of the PPR (for descriptions of characteristics and distributions of these glacial land forms in North Dakota, see Kantrud et al. 1989). Wetland basins in both land forms consisted primarily of temporary, seasonal, semipermanent, and lake classes (Cowardin et al. 1995), which were approximately equivalent to Classes II-V of Stewart and Kantrud (1971).

Field and laboratory methods. - We searched for sandpipers starting in early April of each year by driving 200-250 km each day along arbitrarily selected routes on the study area. Collections began when sandpipers of the studied species first arrived, and continued until all three species had departed for their Arctic breeding grounds in June. We collected by shooting one sandpiper per flock to determine sex, age, body size, and fat content. After being removed from the water, each specimen was dried with paper towels, given an identification number, and placed in a cooler. At the laboratory, we weighed the specimen on a triple beam balance to the nearest $0.1 \mathrm{~g}$, and measured culmen length, tarsus length, and flattened wing chord to the nearest millimeter using a vernier caliper. All body feathers were plucked, an incision was made to expose gonads for sex determination, and reproductive organs were removed and weighed to the nearest $0.1 \mathrm{~g}$. A wing was removed and used to estimate age (adult, yearling) from magnitude and pattern of primary wear, primary shapes, and other wing plumage characteristics (Prater et al. 1977, Gratto and Morrison 1981). Fat content was estimated from subsamples of carcass homogenate (excluding feathers and one wing). Fat extraction was performed on homogenized and dried samples by the Soxhlet process, using petroleum ether and following Official Methods of Analysis (Horwitz 1975). Before fat extraction, samples were dried for $6 \mathrm{~h}$ at $105^{\circ} \mathrm{C}$. Fat-free dry mass (FFDM) was the residue left after fat and water were extracted from the samples. Results are presented as means $\pm \mathrm{SE}$, unless otherwise indicated.

Migration chronology. - We inferred migration chronologies of adult male and female BASA, SESA, and WRSA through North Dakota on the basis of their collection dates. We used two-way analysis of variance (ANOVA) models to determine whether mean date of migration through North Dakota differed between sexes and years for each species.

Body size. - We used multivariate analysis of variance (MANOVA) of the three body measurements (i.e. tarsus length, culmen length, and wing chord) to test for differences in body size between sexes and years for each species. Multivariate analyses that suggested significant differences were followed by separate ANOVA models for each of the three body measurements. We conducted analyses with the generallinear-models procedure (PROC GLM) of SAS (SAS Institute 1999) and used $\alpha=0.05$ for all statistical tests. Body size could have an effect on total body fat; therefore, we considered variation in body size when testing for relationships between total body fat and collection dates. We conducted a principal component analysis (PCA) separately for each species, using the correlation matrix of tarsus length, culmen length, 
and wing chord. The first principal component (PC1) was used as an index of body size. We conducted the PCA using the principal component procedure (PROC PRINCOMP) in SAS.

Fat storage.-We used analysis of covariance (ANCOVA) to examine the relationship between date of collection and total body fat and to test for differences in this relationship between sexes and years. In addition to date of collection as a covariate, we included the body size index (i.e. PC1) as a covariate in the ANCOVAs. We determined the correct form for each covariate following techniques of Milliken and Johnson (2002). We used a means model approach when constructing our models and compared least-squares means between sexes and years using contrasts (Milliken and Johnson 2002). Our models included separate intercept terms for each combination of sex and year and the appropriate slope parameters for the covariates (e.g. common slope parameter, separate slope parameters for each year) as determined above. If the final ANCOVA model is a common slope model (i.e. parallel regression models for each combination of sex and year), differences between least-squares means (i.e. distance between regression lines) will be the same at all values of the covariates and comparisons can be made by comparing the intercepts. However, if the final ANCOVA model is not a common slope model (e.g. separate slopes needed for each year) resulting in nonparallel regression models, differences between least-squares means will not be the same at all values of the covariates. In this case, comparisons of leastsquares means between sexes and years need to be conducted at several values of the covariate. For these comparisons, we chose three to five values of the covariates from within the experimental range for both sexes and years. We conducted ANCOVAs separately for each species, using the mixed linear models procedure (PROC MIXED) of SAS. We used $\alpha=0.05$ for all statistical tests.

Three of 111 observations for BASA ( 2 males in 1980, 1 female in 1981) had values of body mass and total body fat that were markedly higher than the rest of the observations. We excluded these three observations from our analysis because they had undue influence on our results.

Estimation of flight ranges and amount of fat retained at arrival on breeding grounds. - Flight range calculations require assumptions regarding flight conditions and flight speed, for which values are seldom known. We calculated flight ranges after Castro and Myers (1988):

$$
R=(26.88)(S)\left(W^{1.614}\right)\left(M_{E}^{-0.464}-M_{B}^{-0.464}\right)
$$

where $R$ is flight range $(\mathrm{km}), S$ is flight speed $\left(\mathrm{km} \mathrm{h}^{-1}\right), W$ is wing length $(\mathrm{cm}), M_{B}$ is body mass (g) at the start of the flight, and $M_{E}$ is body mass (g) at the end of the flight.

The date for the start of the flight for each individual was assumed to be the average of the last three collection dates for that combination of species, sex, and year. For each individual, we estimated body mass and total body fat for the start of the flight date by starting at the value measured for that individual when collected and assuming they gained at the rate estimated in the ANCOVA model (for that species, sex, and year combination) up to the start of the flight date. Body mass at the end of the flight was the estimated body mass at the start of the flight minus the estimated total body fat at the start of the flight.

Because flight ranges are directly proportional to the assumed flight speed, and assumed flight speeds are highly variable, we chose two flight speeds as selected by Skagen and Knopf (1994) and assumed still air conditions. For one analysis, we assumed a cruising speed of $40 \mathrm{~km} \mathrm{~h}^{-1}$ $\left(11 \mathrm{~m} \mathrm{~s}^{-1}\right)$ for SESA and $45 \mathrm{~km} \mathrm{~h}^{-1}\left(12 \mathrm{~m} \mathrm{~s}^{-1}\right)$ for BASA and WRSA, after Pennycuick's (1969) calculations of the most economical cruising speed of birds based on body mass. For a second analysis, we assumed a higher flight speed of $65 \mathrm{~km} \mathrm{~h}^{-1}\left(18 \mathrm{~m} \mathrm{~s}^{-1}\right)$ after Gudmundsson et al. (1991). Flight distances were estimated from Jamestown, North Dakota $\left(46^{\circ} 54^{\prime} \mathrm{N}\right.$, $98^{\circ} 42^{\prime} \mathrm{W}$ ), within our study area to the nearest known breeding sites for BASA (Moskoff and Montgomerie 2002), SESA (Gratto-Trevor 1992), and WRSA (Parmelee 1992). We calculated actual flight distances using spherical trigonometry and equations from Cowardin (1977).

In the spring of 1980, we captured WRSA and SESA in mist nests at Bird Cove, Churchill, Manitoba $\left(58^{\circ} 04^{\prime} \mathrm{N}, 94^{\circ} 00^{\prime} \mathrm{W}\right)$, from 29 May to 8 June. Semipalmated Sandpipers were also captured during spring 1981 at La Perouse Bay, $40 \mathrm{~km}$ east of Churchill $\left(58^{\circ} 45^{\prime} \mathrm{N}, 93^{\circ} 25^{\prime} \mathrm{W}\right)$, from 28 May to 15 June. All birds were weighed with a Pesola scale to the nearest $0.5 \mathrm{~g}$. 
Results

\section{Migration Schedules}

Baird's Sandpiper.-In 1981, BASA began arriving on our study area about 10 April, two weeks to a month before SESA and WRSA and 10 days earlier than in 1980. Most BASA departed from our study area by 20 May in both years, 2-3 weeks earlier than SESA and WRSA. All 111 collected BASA were adults ( $\geq 2$ years old) and males and females migrated through the study area during the same interval $(F=0.02, \mathrm{df}=1$ and 107, $P=0.89$; Fig. $1 \mathrm{~A})$.

Semipalmated Sandpiper.-On about 5 May in 1980 and 22 April in 1981, SESA started arriving on our study area; numbers peaked from mid- to late May. All but 2 of 99 migrant SESA collected in North Dakota during spring 19801981 were $\geq 2$ years old. Migration of male SESA through our study area averaged earlier (mean Julian date $=143, \mathrm{SE}=1.4$ ) than females (mean Julian date $=148, \mathrm{SE}=1.6)(F=5.81, \mathrm{df}=1$ and 93, $P=0.02$; Fig. 1B).

White-rumped Sandpiper. - In 1980-1981, WRSA began arriving in eastern North Dakota in midto late May (Fig. 1C). Most males preceded females in migration $(t>6.11, \mathrm{df}=120, P<0.01$; Fig. 1C); females were significantly earlier in 1981 than in 1980 (1981: mean Julian date $=150$, $\mathrm{SE}=1.0 ;$ 1980: mean Julian date $=157, \mathrm{SE}=1.0$; $t=5.10, \mathrm{df}=120, P<0.01)$. In 1980-1981, all but one WRSA collected by 20 May were males and nearly all individuals collected after 30 May were females. All 124 WRSA collected during spring stopovers in North Dakota in 1980-1981 were adults ( $\geq 2$ years old).

\section{Body Size}

Baird's Sandpiper.-Body size differed significantly between males and females $(F=15.52$, $\mathrm{df}=3$ and 95, $P<0.01)$ but not between years $(F=$ $1.58, \mathrm{df}=3$ and $95, P=0.20)$. Mean tarsus length, culmen length, and wing chord were all significantly larger for females than for males $(F \geq 4.70$, $\mathrm{df}=1$ and 97, $P<0.04)$. The first principal component (PC1) explained $49 \%$ of variation in the three body measurements, with loadings for the three variables ranging from 0.50 to 0.67 .

Semipalmated Sandpiper.-Body size significantly differed between males and females $(F=$ 35.90, df $=3$ and 91, $P<0.01$ ) but not between
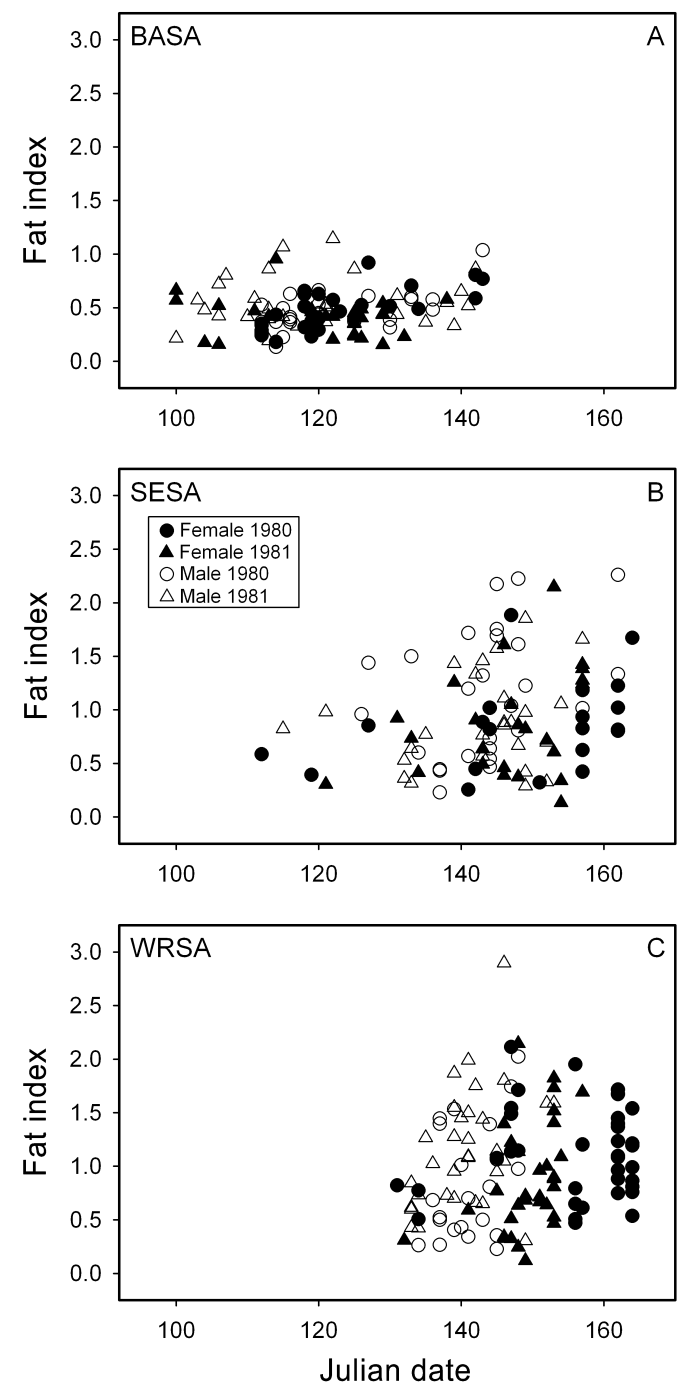

FIG. 1. Chronology of spring migration by male and female (A) Baird's Sandpipers (BASA), (B) Semipalmated Sandpipers (SESA), and (C) White-rumped Sandpipers (WRSA) through eastern North Dakota based on date of occurrence in collections. Fat indices (ratio of fat to fat-free dry mass) are shown by date for collected males and females of each species during stopovers in eastern North Dakota in spring 1980 and 1981.

years $(F=2.24, \mathrm{df}=3$ and $91, P=0.09)$. Mean tarsus length, culmen length, and wing chord were all significantly larger for females than for males $(F \geq 25.33, \mathrm{df}=1$ and 93, $P<0.01)$. The first principal component (PC1) explained 64\% of the variation in the three body measurements, 
with loadings for the three variables ranging from 0.54 to 0.63 .

White-rumped Sandpiper.-Body size differed significantly among sex-and-year combinations $(F=2.72, \mathrm{df}=3$ and $118, P=0.05)$. Mean tarsus length and culmen length were significantly larger for females than for males $(F \geq$ 6.94 $\mathrm{df}=1$ and 120, $P<0.01)$. Differences in mean wing chord between males and females depended on year $(F=5.48, \mathrm{df}=1$ and $120, P=$ $0.02)$. Mean wing chord was significantly larger for females than for males in $1981(t=5.30, \mathrm{df}=$ $120, P<0.01)$ but not in $1980(t=1.70, \mathrm{df}=120$, $P=0.09)$. Also, mean wing chord was significantly larger in 1980 than in 1981 for males $(t=$ $2.31, \mathrm{df}=120, P=0.02)$ but not for females $(t=$ $-0.93, \mathrm{df}=120, P=0.36)$. The first principal component (PC1) explained $53 \%$ of the variation in the three body measurements, with loadings for the three variables ranging from 0.53 to 0.65 . Although WRSA typically have a polygynous breeding system (Parmelee 1992), bill, tarsus, wing, and body-mass measurements were as sex-reversed as those of the monogamous biparental BASA and SESA (Table 1).

\section{Fat Storage}

Fat indices (ratio of fat to $\mathrm{ffdm}$ ) of male and female BASA averaged $0.46 \pm 0.03(n=26)$ and $0.48 \pm 0.04(n=27)$ in 1980, and $0.55 \pm 0.04(n=$ $30)$, and $0.41 \pm 0.04(n=25)$ in 1981 (Fig. 1A). Fat indices of male and female SESA averaged $1.13 \pm 0.12(n=27)$ and $0.93 \pm 0.11(n=19)$ in 1980 , and $0.87 \pm 0.09(n=26)$ and $0.86 \pm 0.10$ $(n=25)$ in 1981 (Fig. 1B). Fat indices for male and female WRSA averaged $0.84 \pm 0.11(n=22)$ and $1.13 \pm 0.07(n=37)$ in 1980 , and $1.14 \pm 0.10$ $(n=34)$ and $0.94 \pm 0.10(n=31)$ in 1981 (Fig. 1C).
Baird's Sandpiper. - We rejected the hypothesis that the relationship between date and total body fat was the same for all combinations of sex and year $(F=4.16, \mathrm{df}=3$ and $86, P=0.01)$. Separate slope parameters were needed for each year $(F=12.40, \mathrm{df}=1$ and $92, P<0.01)$, but not for each $\operatorname{sex}(F=1.23, \mathrm{df}=1$ and $91, P=0.27)$ or for combinations of sex and year $(F=0.70, \mathrm{df}=$ 1 and 90, $P=0.40$; Table 2; Fig. 2A). We did not detect a significant relationship between total body fat and body size $(F=0.23, \mathrm{df}=1$ and 89 , $P=0.63)$; therefore, PC1 was dropped from the final model.

We detected significant differences in mean total body fat between males and females in $1981(t=-2.23, \mathrm{df}=92, P=0.03)$ but not in 1980 $(t=1.10, \mathrm{df}=92, P=0.27)$; males had significantly more total body fat than females in 1981. Because different slopes were used for each year, we compared means between years at several dates. Mean total body fat differed significantly between years for males at Julian dates 114 and $142(|t| \geq 2.44, \mathrm{df}=92, P<0.02)$ but not at Julian dates 121, 128, and $135(|t| \leq 1.80, \mathrm{df}=$ $92, P>0.07)$. We detected significant differences in mean total body fat between years for females at Julian dates 121, 128, 135, and $142(|t| \geq 1.96$, $\mathrm{df}=92, P \leq 0.05)$, but not at Julian date $114(t=$ $0.17, \mathrm{df}=92, P=0.87)$.

Semipalmated Sandpiper. - We failed to reject the hypothesis that the relationship between date and total body fat was the same for all combinations of sex and year $(F=0.36, \mathrm{df}=3$ and $85, P=0.78)$. Therefore, a common slope parameter was used for date (slope $=0.0795$, $\mathrm{SE}=0.0268$; Table 2; Fig. 2B). We did not detect a significant relationship between total body fat and body size $(F=1.04, \mathrm{df}=1$ and $91, P=0.31)$, so PC1 was dropped from the final model. We did

TABLE 1. Standard body measurements (mean \pm SE) of adult male and female Baird's Sandpipers (BASA), Semipalmated Sandpipers (SESA), and White-rumped Sandpipers (WRSA) collected in North Dakota during spring 1980 and 1981.

\begin{tabular}{lcccccr}
\hline Species & Sex & $n$ & $\begin{array}{c}\text { Body mass } \\
(\mathrm{g})\end{array}$ & $\begin{array}{c}\text { Bill length } \\
(\mathrm{mm})\end{array}$ & $\begin{array}{c}\text { Tarsus length } \\
(\mathrm{mm})\end{array}$ & $\begin{array}{c}\text { Wing chord } \\
(\mathrm{mm})\end{array}$ \\
\hline BASA & M & 53 & $41.14 \pm 0.52$ & $22.18 \pm 0.13$ & $23.22 \pm 0.14$ & $126.21 \pm 0.41$ \\
& F & 48 & $42.17 \pm 0.52$ & $23.55 \pm 0.19$ & $23.68 \pm 0.14$ & $128.79 \pm 0.55$ \\
SESA & M & 53 & $29.25 \pm 0.51$ & $18.27 \pm 0.11$ & $22.09 \pm 0.12$ & $98.32 \pm 0.36$ \\
& F & 44 & $31.21 \pm 0.57$ & $20.22 \pm 0.16$ & $22.97 \pm 0.12$ & $101.34 \pm 0.47$ \\
WRSA & M & 56 & $46.09 \pm 0.84$ & $22.87 \pm 0.13$ & $25.11 \pm 0.15$ & $123.07 \pm 0.40$ \\
& F & 68 & $48.92 \pm 0.69$ & $24.53 \pm 0.09$ & $25.60 \pm 0.11$ & $125.69 \pm 0.33$ \\
\hline
\end{tabular}


TABle 2. Final models used to examine relationship of total body fat ( $\mathrm{g}$ ) with Julian date by sex and year for Baird's Sandpiper, Semipalmated Sandpiper, and White-rumped Sandpiper during stopovers in eastern North Dakota during spring 1980 and 1981.

\begin{tabular}{lccl}
\hline \hline Species & Sex & Year & \multicolumn{1}{c}{ Final model } \\
\hline Baird's Sandpiper & F & 80 & Total body fat $=-8.2626+0.1024$ * date \\
& M & 80 & Total body fat $=-8.7181+0.1024$ * date \\
& F & 81 & Total body fat $=3.2594+0.0006$ date \\
Semipalmated Sandpiper & F & 81 & Total body fat $=4.0770+0.0006$ date \\
& M & 80 & Total body fat $=-6.7147+0.0795 *$ date \\
& F & 81 & Total body fat $=-5.5813+0.0795 *$ date \\
White-rumped Sandpiper & Total body fat $=-6.5749+0.0795 *$ date \\
& F & 81 & Total body fat $=-6.6490+0.0795 *$ date \\
& M & 80 & Total body fat $=14.4756-0.0283 *$ date \\
& F & 81 & Total body fat $=-56.9503+0.4570 *$ date \\
& Total body fat $=-67.0876+0.5012 *$ date \\
\hline
\end{tabular}
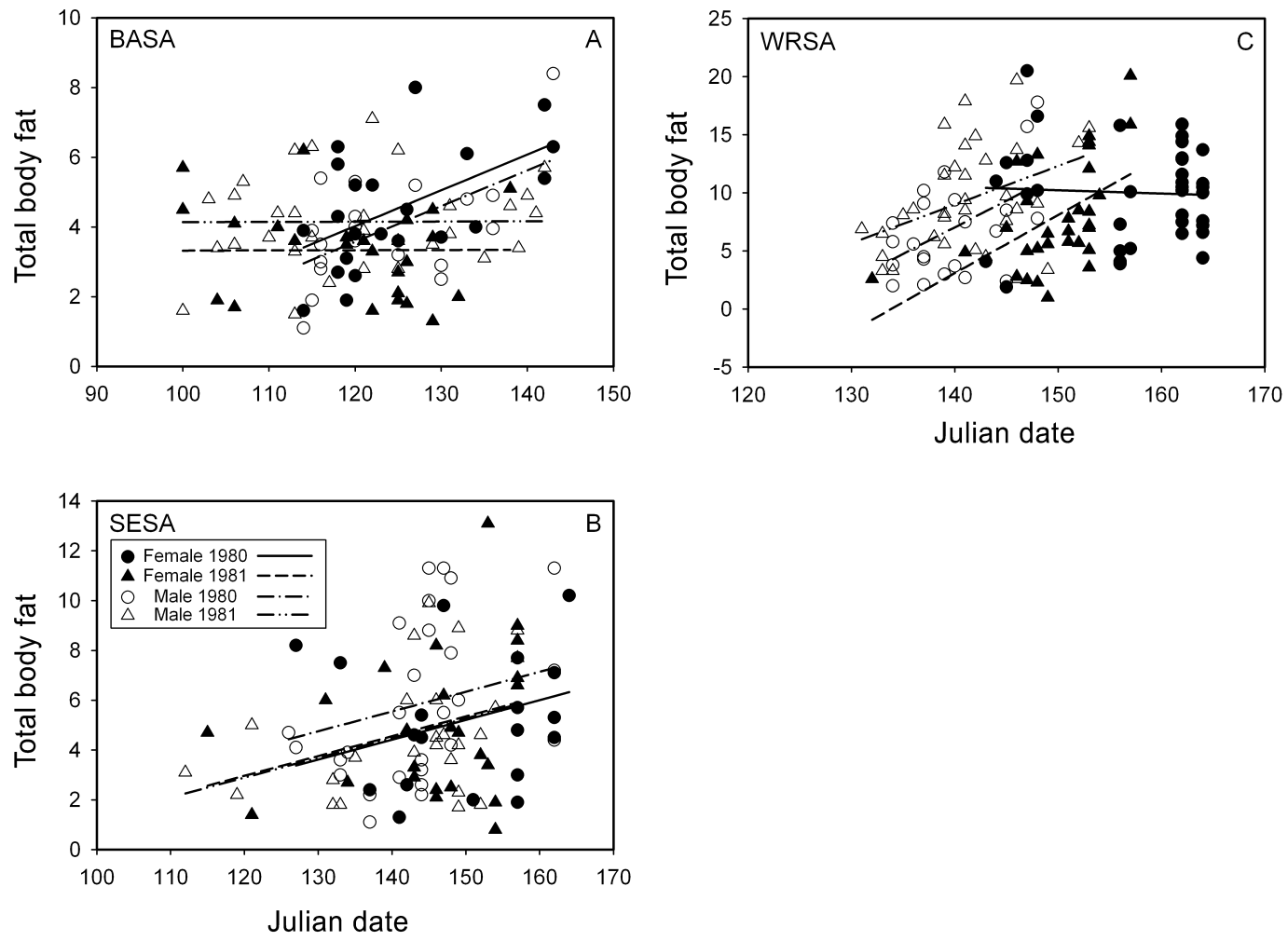

Fig. 2. Total body fat by date in adult male and female (A) Baird's Sandpipers (BASA), (B) Semipalmated Sandpipers (SESA), and (C) White-rumped Sandpipers (WRSA) in spring 1980 and 1981 during stopovers in eastern North Dakota. 
not observe significant differences in mean total body fat between males and females in either year $(|t| \leq 1.37, \mathrm{df}=92, P>0.17)$ or between years for either sex $(|t| \leq 1.43, \mathrm{df}=92, P>0.15)$.

White-rumped Sandpiper.-We rejected the hypothesis that the relationship between date and total body fat was the same for all combinations of sex and year $(F=3.55, \mathrm{df}=3$ and 112, $P=0.02$; Fig. 2C). Separate slope parameters were needed for each combination of sex and year $(F=4.93, \mathrm{df}=1$ and $116, P=0.04$; Fig. 2C). We did not detect a significant relationship between total body fat and body size $(F=$ $0.46, \mathrm{df}=1$ and 115, $P=0.50)$; therefore, PC1 was dropped from the model (Table 2). Because different slopes were used for each combination of sex and year, we compared means between years and sexes at several dates. We detected significant differences in mean total body fat between males and females at all three dates examined (i.e. Julian dates 140, 146, and 152) for $1981(|t| \geq 2.18, \mathrm{df}=116, P \leq 0.03)$ but not at any of the three dates examined (i.e. Julian dates 143,146 , and 149) for $1980(|t| \leq 1.11, \mathrm{df}=116$, $P>0.2$; Fig. 2C). Mean total body fat significantly differed between years for females at Julian dates 143 and $149(|t| \geq 2.12$, df $=116, P<0.04)$ but not at Julian date $155(\mathrm{t}=-0.39, \mathrm{df}=116, P=$ 0.69 ). We did not detect significant differences in mean total body fat between years for males at any of the dates examined (i.e. Julian dates 134, 140, and 146: $|t| \leq 1.73, \mathrm{df}=116, P>0.08)$.

\section{Estimated Flight Ranges and Fat Reserves at Arrival on Breeding Grounds}

The closest distances (in kilometers) from the study area to the nearest known breeding areas for BASA, SESA, and WRSA were estimated to be 2,015, 1,191, and 1,888 km, respectively. Flight ranges are a function of flight speed, and at $40 \mathrm{~km} \mathrm{~h}^{-1}$ (SESA) and $45 \mathrm{~km} \mathrm{~h}^{-1}$ (BASA, WRSA), flight ranges are $38 \%$ and $31 \%$ less, respectively, than at $65 \mathrm{~km} \mathrm{~h}^{-1}$ (Table 3). Flight ranges of BASA when flying at $65 \mathrm{~km} \mathrm{~h}^{-1}$ are estimated to average $24-43 \%$ less than those of SESA and WRSA, respectively, on the basis of predicted fat and body mass at the end of spring staging. No BASA are estimated to have reached the breeding grounds relying exclusively on fat reserves, whether flying at $45 \mathrm{~km} \mathrm{~h}^{-1}$ or at $65 \mathrm{~km} \mathrm{~h}^{-1}$ (Table 3). Comparing means by sex and year, estimated flight ranges of BASA were $8-62 \%$ less than for SESA and

TABLE 3. Estimated flight ranges (mean \pm SE) of adult male and female Baird's Sandpipers (BASA), Semipalmated Sandpipers (SESA), and White-rumped Sandpipers (WRSA) when departing the North Dakota study area in 1980 and 1981 at flight speeds of $40 \mathrm{~km} \mathrm{~h}^{-1}$ (SESA), $45 \mathrm{~km} \mathrm{~h}^{-1}$ (BASA, WRSA), and $65 \mathrm{~km} \mathrm{~h}^{-1}$ (all three species) (Castro and Myers 1989), based on fat loads present at the end of the spring staging interval.

\begin{tabular}{|c|c|c|c|c|c|c|c|}
\hline \multirow[b]{2}{*}{ Species } & \multirow[b]{2}{*}{ Sex } & \multirow[b]{2}{*}{ Year } & \multirow[b]{2}{*}{$n$} & \multicolumn{2}{|c|}{$\begin{array}{l}\text { Flight range }(\mathrm{km}) \\
\quad(\text { mean } \pm \text { SE })\end{array}$} & \multicolumn{2}{|c|}{$\begin{array}{l}\text { Estimated fat (g) reserve at } \\
\text { arrival on breeding site }\end{array}$} \\
\hline & & & & $\begin{array}{l}\text { Flight speed } \\
40-45 \mathrm{~km} \mathrm{~h}^{-1}\end{array}$ & $\begin{array}{c}\text { Flight speed } \\
65 \mathrm{~km} \mathrm{~h}^{-1}\end{array}$ & $\begin{array}{l}\text { Flight speed } \\
40-45 \mathrm{~km} \mathrm{~h}^{-1}\end{array}$ & $\begin{array}{c}\text { Flight speed } \\
65 \mathrm{~km} \mathrm{~h}^{-1}\end{array}$ \\
\hline BASA & $\begin{array}{l}\text { M } \\
F \\
M \\
F\end{array}$ & $\begin{array}{l}1980 \\
1980 \\
1981 \\
1981\end{array}$ & $\begin{array}{l}26 \\
27 \\
30 \\
25\end{array}$ & $\begin{array}{l}989 \pm 37 \\
931 \pm 29 \\
633 \pm 38 \\
511 \pm 41\end{array}$ & $\begin{array}{r}1429 \pm 53 \\
1345 \pm 42 \\
914 \pm 55 \\
739 \pm 59\end{array}$ & $\begin{array}{l}(0) \\
(0) \\
(0) \\
(0)\end{array}$ & $\begin{array}{l}(0) \\
(0) \\
(0) \\
(0)\end{array}$ \\
\hline SESA & $\begin{array}{l}\mathrm{M} \\
\mathrm{F} \\
\mathrm{M} \\
\mathrm{F}\end{array}$ & $\begin{array}{l}1980 \\
1980 \\
1981 \\
1981\end{array}$ & $\begin{array}{l}27 \\
19 \\
26 \\
25\end{array}$ & $\begin{array}{r}1013 \pm 72 \\
896 \pm 80 \\
842 \pm 55 \\
810 \pm 67\end{array}$ & $\begin{array}{l}1646 \pm 116 \\
1456 \pm 130 \\
1367 \pm 90 \\
1316 \pm 108\end{array}$ & $\begin{array}{c}2.25(33) \\
1.55(26) \\
0.48(15) \\
5.21(4)\end{array}$ & $\begin{array}{l}3.48(70) \\
2.81(63) \\
2.27(62) \\
2.39(60)\end{array}$ \\
\hline WRSA & $\begin{array}{c}M \\
F \\
M \\
F\end{array}$ & $\begin{array}{l}1980 \\
1980 \\
1981 \\
1981\end{array}$ & $\begin{array}{l}22 \\
37 \\
34 \\
31\end{array}$ & $\begin{array}{l}1313 \pm 83 \\
1224 \pm 75 \\
1520 \pm 67 \\
1329 \pm 79\end{array}$ & $\begin{array}{l}1897 \pm 120 \\
1767 \pm 108 \\
2196 \pm 97 \\
1921 \pm 114\end{array}$ & $\begin{array}{c}1.33(9) \\
0.98(8) \\
3.16(15) \\
1.57(16)\end{array}$ & $\begin{array}{l}3.09(50) \\
3.70(38) \\
4.01(71) \\
4.45(42)\end{array}$ \\
\hline
\end{tabular}

${ }^{a}$ Mean estimated fat loads (g) carried by male and female BASA, SESA, and WRSA that had not exhausted all of their fat reserves at arrival on the nearest parts of their breeding ranges, assuming that energy requirements for migration were met solely from stored fat reserves acquired before departing from North Dakota. Estimated percentages of sandpipers that arrived on their breeding grounds retaining part of the fat reserves acquired before departure from North Dakota are given in parentheses. 
WRSA (Table 3). Estimated flight ranges of adult male and female BASA and SESA declined by $36 \%$ and $45 \%$ and $17 \%$ and $10 \%$, respectively, from 1980 to 1981, whereas estimated flight ranges of male and female WRSA increased by $16 \%$ and $9 \%$. Among the $25 \%$ of male and female SESA and WRSA with the highest predicted fat loads and flying at $65 \mathrm{~km} \mathrm{~h}^{-1}$, we estimated that fat was sufficient to meet all energy costs needed to reach the nearest parts of their breeding ranges and still leave an estimated 52.5\% and $46.4 \%$, and $37.0 \%$ and $35.3 \%$, of fat stored by departure from North Dakota to contribute to reproductive needs.

In late May 1980 to early June 1981, SESA captured and weighed shortly after arrival near Churchill, Manitoba, at the southeast edge of the species' breeding range, had mean fresh body masses averaging $27.0 \pm 0.2 \mathrm{~g}(n=107)$, and $26.6 \pm 0.6 \mathrm{~g}(n=12)$, or about 3.5 and $4.4 \mathrm{~g}$ less than unsexed SESA (males and females combined) in North Dakota on 28 May (Julian date 149) near the end of spring staging. Male and female SESA in North Dakota with body masses equivalent to unsexed SESA at Churchill carried $\sim 3 \mathrm{~g}$ of fat, which suggests that birds at Churchill retained $\sim 55 \%$ of fat (average predicted fat for date 149 in North Dakota is $5.5 \mathrm{~g}$ ), on average, when departing from North Dakota on 28 May (Fig. 2B).

In early June 1980, unsexed WRSA captured and measured near Churchill, Manitoba, $\sim 400 \mathrm{~km}$ south of the southern edge of their breeding range, had fresh body masses averaging $42.0 \pm$ $1.9 \mathrm{~g}(n=218)$ or $\sim 7.3 \mathrm{~g}$ less than WRSA (sexes combined) collected in North Dakota between Julian dates 140 and 150, which averaged $49.3 \pm$ $1.7 \mathrm{~g}(n=20)$. White-rumped Sandpipers in North Dakota with fresh body masses equivalent to those at Churchill averaged $\sim 5 \mathrm{~g}$ of fat. Male and female WRSA in North Dakota (sexes combined) contained $9.7 \pm 1.2 \mathrm{~g}(n=20)$ fat, which suggests that $\sim 52 \%$ of fat stored by departure from North Dakota was retained at arrival at Churchill.

\section{Discussion}

\section{Fat Storage}

Differences in migration schedules of male and female WRSA through temperate midcontinental North America in spring 1980 likely contributed to sex-related variation in fat reserves during spring in North Dakota. Adult male WRSA, by migrating earlier than females, may have encountered foraging conditions that differed from females; migration schedules of male and female SESA and BASA overlapped broadly, which presumably reduced sex-related variation in fat storage. By migrating earlier, male WRSA arrive on their breeding grounds before females, which provides them with more time to locate high-quality territories (Myers 1981, Oring and Lank 1982, Ketterson and Nolan 1983) and achieve multiple mating opportunities (Oring and Lank 1982, Reynolds et al. 1986), therefore increasing their probability of reproductive success. Female WRSA are solely responsible for incubating clutches and rearing broods (Parmelee et al. 1968), whereas both sexes of SESA and BASA share equally in incubation (Norton 1972, Gratto-Trevor 1992), and male SESA provide the majority of brood care. Females of all three species were larger than males, which may be related to sexual selection through competition for mates. Females are larger in polygynous species where male aerial displays involve agility (e.g. WRSA), and in socially monogamous species (e.g. BASA and SESA), regardless of male agility (Székely et al. 2000).

Female WRSA arrived in North Dakota in 1980 with fat reserves already acquired, which suggests that, at least in some years, female WRSA acquire a major part of their fat reserves before reaching the PPR. The Cheyenne Bottoms in Kansas have been identified as an important fat-storage area for WRSA in spring migration (Harrington et al. 1991). We do not know where female WRSA that we measured acquired fat before arriving in North Dakota in 1980 and 1981, but an estimated 17,000 WRSA stopped at Cheyenne Bottoms in spring 1980, in contrast to only 1,000 in 1981 (B. Harrington unpubl. data, Manomet Center for Conservation Sciences, Manomet, Massachusetts), which is consistent with female WRSA arriving in North Dakota with higher fat loads in 1980.

Baird's Sandpipers commonly stop at wetlands in the Playa Lakes Region of Texas (Davis and Smith 1998) and central Great Plains (Skagen et al. 1999) during spring migration, so wetland habitat conditions in these regions may influence migration schedules and amounts of fat carried to the PPR. Baird's Sandpipers stored 
about half as much fat as SESA and WRSA before departing from North Dakota. An earlier migration by BASA probably contributed to less fat being stored, because maintenance energy requirements increase as ambient temperatures decline (Kendeigh et al. 1977). Also, aquatic macro-invertebrates are less available in the PPR in early spring than later (Murkin and Ross 2000), potentially contributing to less fat storage. Lower ambient temperatures in April and May 1981 than in 1980 may have contributed to fat reserves of BASA not increasing during stopovers in North Dakota in 1981. Ambient temperatures during April and May 1981 averaged $1.6^{\circ} \mathrm{C}$ and $3.2^{\circ} \mathrm{C}$ lower at Jamestown, North Dakota, than in 1980 (National Oceanic and Atmospheric Administration 1980-1981).

Dynamic patterns of precipitation and hydrology in the Great Plains cause extreme temporal and spatial variation in availability of mudflat habitat productive of foods sought by Arcticnesting sandpipers. Severe regional droughts or other influences that limit foraging opportunities by sandpipers have the potential to reduce fat storage. Our study did not include a spring when productive mudflat habitat was scarce, but for SESA and WRSA, we compared our findings with measurements made during 1990 and 1992, when a major drought was underway in the northern Great Plains. In springs 1990 and 1992, fresh body masses of SESA and WRSA captured and measured at Little Quill Lake, Saskatchewan, averaged $26.2 \pm 0.1 \mathrm{~g}(n=724)$ and $42.1 \pm 1.0 \mathrm{~g}$ $(n=16)$ (Alexander and Gratto-Trevor 1997), or $13 \%$ and $12 \%$ less than during springs 1980-1981 in North Dakota (present study). Mean body mass of SESA at Quill Lake was negatively correlated with date in 1990 and only slightly positively correlated with date in 1992 (Alexander and GrattoTrevor 1997). Semipalmated Sandpipers and WRSA had already migrated across most of the northern Great Plains by their stopover at Little Quill Lake, limiting opportunities for additional fat storage. These patterns suggest that the magnitude of fat storage in Arctic-nesting sandpipers during spring is influenced by amount and condition of wetland habitat available in temperate North America.

\section{Flight-range Estimates and Fat Use}

Flight-range estimates should be interpreted with caution and are most useful as relative measures for comparisons among species (Gudmundsson et al. 1991). On the basis of our flight-range estimates, BASA arrived on the breeding grounds with limited fat for use in reproduction. Because BASA migrate earlier than SESA and WRSA, it is possible that they acquired a greater part of their fat reserves north of our study area than SESA and WRSA. However, it is unlikely that BASA, after departing from North Dakota, were able to markedly increase fat storage. In the years studied, BASA probably stored less fat in temperate midcontinental North America than SESA and WRSA.

Fresh body masses of live-trapped SESA, when measured on or near their subArctic and Arctic breeding grounds in Canada during 1980 and 1981, had estimated fat levels consistent with the amount of fat we estimated to remain after subtracting fat used to sustain flights of $65 \mathrm{~km} \mathrm{~h}^{-1}$ to the breeding grounds. Both estimates suggest that most of the SESA retained significant amounts of fat upon arrival at the southern edge of the breeding range. Fresh body masses of live-trapped WRSA measured shortly after arrival at Churchill in late May and early June 1980 suggested that about half of the fat reserves they had acquired before departing from North Dakota were retained at $\sim 400 \mathrm{~km}$ from the nearest part of their breeding range. Information from measurements of WRSA live-trapped near Churchill and from flightrange estimates both suggest that a major part of the WRSA population retained sufficient fat upon arrival at the closest part of their breeding range in 1980 to contribute to nutrient needs for reproduction. Semipalmated Sandpipers and WRSA nesting at higher latitudes and farther from temperate staging areas likely retain proportionally less fat at the onset of the breeding season, which may lead to smaller percentages of populations breeding successfully.

Our results show wide variation in amounts of fat that SESA and WRSA carried to their breeding grounds, which is presumably related, in part, to success of individual birds at locating productive foraging sites during their migration through temperate mid-continental North America. Female SESA and WRSA that arrive early on the breeding grounds with large amounts of fat likely draw on this reserve to supply part of their fat requirements for egg production. However, endogenous fat is probably more important as a source of energy for survival after arrival, 
particularly when environmental conditions are severe, and for enabling physiological changes necessary for breeding to take place early in the season, when food is scarce (also see Morrison and Hobson 2004). In the central Canadian Arctic, many female SESA do not attempt to nest in years with harsh weather conditions, and females normally have higher mortality rates than males (Gratto-Trevor 1992). Consequently, female sandpipers that arrive on the breeding grounds with limited fat reserves, whether because of poor wetland habitat conditions in temperate North America or adverse weather encountered during migration, presumably are less likely to survive and reproduce successfully. Further research is needed to gain more insight into how annual variations in wetland water conditions, weather, and human-induced alterations of wetlands in temperate North America affect fat loads that Arctic-nesting sandpipers carry when departing for their breeding grounds in spring, and into relations between fat loads and fitness.

\section{AcKnowledgments}

Field research in North Dakota was funded primarily by the U.S. Fish and Wildlife Service. We are grateful to R. Atkins, M. Meyer, M. Rabenberg, and C. Shaiffer for assisting in data collection on the North Dakota study site, along with numerous landowners that allowed access to their properties. We also want to thank B. Harrington, D. Haukos, R. Cox, G. Sargeant, and two anonymous reviewers for helpful comments on earlier drafts of this manuscript and the Canadian Wildlife Service (Environment Canada) and Queens University, Kingston, Ontario, for logistical support provided to C. Gratto-Trevor during studies of Arctic-nesting shorebirds in northern Canada.

\section{Literature Cited}

Alexander, S. A., and C. L. Gratto-Trevor. 1997. Shorebird migration and staging at a large prairie lake and wetland complex: The Quill Lakes, Saskatchewan. Canadian Wildlife Service Occasional Paper, no. 97, Ottawa, Ontario.

Castro, G., and J. P. Myers. 1988. A statistical method to estimate the cost of flight in birds. Journal of Field Ornithology 59:369-380.

CowArdin, L. M. 1977. Analysis and machine mapping of the distribution of band recoveries. U.S. Department of the Interior, Fish and Wildlife Service, Special Scientific Report-Wildlife, no. 198.

Cowardin, L. M., T. L. Shaffer, and P. M. ArNold. 1995. Evaluations of duck habitat and estimation of duck population sizes with a remote-sensing-based system. National Biological Service Biological Science Report, no. 2.

Davis, C. A., And L. M. Sмith. 1998. Ecology and management of migrant shorebirds in the Playa Lakes Region of Texas. Wildlife Monographs, no. 140.

Gratto, C. L., and R. I. G. Morrison. 1981. Partial postjuvenile wing moult of the Semipalmated Sandpiper (Calidris pusilla). Wader Study Group Bulletin 33:33-37.

Gratto-Trevor, C. L. 1992. Semipalmated Sandpiper (Calidris pusilla). In The Birds of North America, no. 6 (A. Poole, P. Stettenheim, and F. Gill, Eds.). Academy of Natural Sciences, Philadelphia, and American Ornithologists' Union, Washington, D.C.

Gudmundsson, G. A., Å. Lindström, And T. Alerstam. 1991. Optimal fat loads and long distance flights by migrating Knots (Calidris canutus), Sanderlings (C. alba), and Turnstones (Arenaria interpres). Ibis 133:140-152.

Harrington, B. A., F. J. Leeunenberg, S. L. Resende, R. McNeil, B. T. Thomas, J. S. Grear, and E. F. Martinez. 1991. Migration and mass change of White-rumped Sandpipers in North and South America. Wilson Bulletin 103:621-636.

Horwitz, W. 1975. Official Methods of Analysis, 12th ed. Association of Official Analytical Chemists, Washington, D.C.

Kantrud, H. A., G. L. Krapu, and G. A. Swanson. 1989. Prairie basin wetlands of the Dakotas: A community profile. U.S. Department of the Interior, Fish and Wildlife Service, Biological Report, no. 85.

Kendeigh, S. C., V. R. Dol'Nik, and V. M. Gavrilov. 1977. Avian energetics. Pages 127-204 in Granivorous Birds in Ecosystems: Their Evolution, Populations, Energetics, Adaptations, Impact and Control (J. Pinowski and S. C. Kendeigh, Eds.). Cambridge University Press, Cambridge, United Kingdom.

Ketterson, E. D., and V. Nolan, Jr. 1983. The evolution of differential bird migration. Pages 
357-402 in Current Ornithology, vol. 1 (R. F. Johnston, Ed.). Plenum Press, New York.

Krapu, G. L., and H. F. Duebbert. 1989. Prairie wetlands: Characteristics, importance to waterfowl, and status. Pages 811-828 in Freshwater Wetlands and Wildlife (R. R. Sharitz and J. W. Gibbons, Eds.). U.S. Department of Energy Symposium Series 61, Office of Scientific and Technical Information, Oak Ridge, Tennessee.

Milliken, G. A., And D. E. Johnson. 2002. Analysis of Messy Data, vol. III: Analysis of Covariance. Chapman and Hall/CRC, Boca Raton, Florida.

Morrison, R. I. G. 1984. Migration systems of some New World shorebirds. Pages 125-202 in Behavior of Marine Animals, vol. 6 (J. Burger and B. L. Olla, Eds.). Plenum Press, New York.

Morrison, R. I. G., Y. Aubry, R. W. Butler, G. W. Beyersbergen, G. M. Donaldson, C. L. Gratto-Trevor, P. W. Hicklin, V. H. Johnston, And R. K. Ross. 2001. Declines in North American shorebird populations. Wader Study Group Bulletin 94:34-38.

Morrison, R. I. G., C. Downes, and B. Collins. 1994. Population trends of shorebirds on fall migration in eastern Canada 1974-1991. Wilson Bulletin 106:431-447.

Morrison, R. I. G., And K. A. Hobson. 2004. Use of body stores in shorebirds after arrival on high-Arctic breeding grounds. Auk 121: 333-344.

Moskoff, W., and R. Montgomerie. 2002. Baird's Sandpiper (Calidris bairdii). In The Birds of North America, no. 661 (A. Poole and F. Gill, Eds.). Birds of North America, Philadephia.

Murkin, H. R., and L. C. M. Ross. 2000. Invertebrates in prairie wetlands. Pages 201-247 in Prairie Wetland Ecology (H. R. Murkin, A. G. van der Valk, and W. R. Clark, Eds.). Iowa State University Press, Ames.

Myens, J. P. 1981. A test of three hypotheses for latitudinal segregation of the sexes in wintering birds. Canadian Journal of Zoology 59:1527-1534.

National Oceanic AND Atmospheric Administration. 1980-1981. Climatological data: North Dakota monthly summaries. National Climatic Data Center, Asheville, North Carolina.

Norton, D. W. 1972. Incubation schedules of four species of calidridine sandpipers at Barrow, Alaska. Condor 74:164-176.

ORING, L. W., AND D. B. LANK. 1982. Sexual selection, arrival times, philopatry, and site fidelity in the polyandrous Spotted Sandpiper. Behaviorial Ecology and Sociobiology 10: 185-191.

Parmelee, D. F. 1992. White-rumped Sandpiper (Calidris fuscicollis). In The Birds of North America, no. 29 (A. Poole, P. Stettenheim, and F. Gill, Eds.). Academy of Natural Sciences, Philadephia, and American Ornithologists' Union, Washington, D.C.

Parmelee, D. F., D. W. Greiner, and W. D. Graul. 1968. Summer schedule and breeding biology of the White-rumped Sandpiper in the central Canadian Arctic. Wilson Bulletin 80:5-29.

Pennycuick, C. J. 1969. The mechanics of bird migration. Ibis 111:525-556.

Prater, A. J., J. H. Marchant, and J. Vuorinen. 1977. Guide to the Identification and Ageing of Holarctic Waders. BTO Field Guide 17, British Trust for Ornithology, Tring, United Kingdom.

Reynolds, J. D., M. A. Colwell, and F. Cooke. 1986. Sexual selection and spring arrival times of Red-necked and Wilson's phalaropes. Behaviorial Ecology and Sociobiology 18:303-310.

SAS InStituTE. 1999. SAS OnlineDoc, version 8. SAS Institute, Cary, North Carolina.

Skagen, S. K., AND F. L. Knopf. 1994. Residency patterns of migrating sandpipers at a midcontinental stopover. Condor 96:949-958.

Skagen, S. K., P. B. Sharpe, R. G. Waltermire, AND M. B. Dillon. 1999. Biogeographical profiles of shorebird migration in midcontinental North America. U.S. Department of the Interior and U.S. Geological Survey, Biological Science Report USGS/BRD/BSR2000-0003.

Stewart, R. E., and H. A. Kantrud. 1971. Classification of natural ponds and lakes in the glaciated prairie region. Resource Publication 92, U.S. Fish and Wildlife Service, Washington, D.C.

SzéKely, T., J. D. Reynolds, and J. Figuerola. 2000. Sexual size dimorphism in shorebirds, gulls, and alcids: The influence of sexual and natural selection. Evolution 54:1404-1413.

Associate Editor: D. A. Haukos 